\title{
Allergy to Ailanthus altissima Pollen: A Local Allergen to Consider
}

Martí-Garrido $\mathrm{J}^{1}$, Corominas $\mathrm{M}^{1}$, Castillo-Fernández $\mathrm{M}^{2}$, Belmonte $\mathrm{J}^{3,4}$, Pineda $\mathrm{F}^{2}$, Lleonart $\mathrm{R}^{1}$

${ }^{1}$ Allergology Service, Hospital Universitari de Bellvitge-IDIBELL L'Hospitalet de Llobregat, Barcelona, Spain

${ }^{2}$ DIATER Laboratories, Madrid, Spain

${ }^{3}$ Institut de Ciència i Tecnologia Ambientals, Universitat Autònoma de Barcelona, Cerdanyola del Vallès, Barcelona, Spain ${ }^{4}$ Department of Animal Biology, Plant Biology and Ecology, Universitat Autònoma de Barcelona, Cerdanyola del Vallès, Barcelona, Spain

J Investig Allergol Clin Immunol 2020; Vol. 30(6): 452-454 doi: $10.18176 /$ jiaci.0577

Key words: Ailanthus altissima. Allergy. Hypersensitivity. Pollen. Rhinitis. Palabras clave: Ailanthus altissima. Alergia. Hipersensibilidad. Polen. Rinitis.

The diagnostic work-up for pollen allergy must include species with allergenic potential that are specific to an area. Although the most prevalent pollens are well-known and studied in our geographical area (Barcelona, Spain), in order to achieve an accurate diagnosis, we should also take into account recently introduced species.

We present the case of a 42-year-old woman who had experienced rhinoconjunctivitis (sneezing, rhinorrhea, nasal and ocular pruritus, and tearing) between May and June for the previous 3 years. She related her symptoms to the presence of certain trees near her home. The trees were identified as Ailanthus altissima.

$A$ altissima, also known as the tree of heaven, is a dioecious plant that is native to China and was introduced as an ornamental species in Spain in the XIX century. It has become naturalized and invasive [1]. Some plants produce hermaphrodite flowers, and others only male flowers, which tend to be 4 times more abundant than plants that produce female flowers. The pollen grain is spheroidal and isopolar, medium-sized (26 $\mu \mathrm{m}$, varying from 24.3-28.7 $\mu \mathrm{m}$ ), tricolporate, and striato-reticulate. Pollination is from May to July [2]. The database of the Catalan Aerobiological Network (http://lap.uab.cat/aerobiologia) shows that for the Barcelona area and the period 1994-2019, the pollen grains from Ailanthus species are airborne from the second week of May until the end of June, with a sporadic presence during July.

In order to study A altissima sensitization in the present case, we collected pollen from male trees during the pollen season and obtained a protein extract. The protein content measured by the Bradford method was $0.14 \mathrm{mg} / \mathrm{mL}$ of extract. After obtaining the patient's consent, we performed skin prick tests with the most prevalent aeroallergens in our environment (Cupressus, Platanus, Olea, Parietaria, 
Artemisia, Salsola, Acer, Alnus, Betula, Castanea, Celtis, Corylus, Eucalyptus, Fagus, Ligustrum, Morus, Phoenix, Pinus, Populus, Prunus, Quercus, Robinia, Salix, Ulmus, and grass pollen mix, as well as house dust mites, dog and cat dander, and molds [Laboratorios LETI, Spain]). We also performed skin testing with $A$ altissima pollen extract. Histamine hydrochloride and glycerol saline were used as a positive and negative control, respectively. Two atopic patients served as controls.

The protein components of the pollen extract were separated by sodium dodecyl sulfate-polyacrylamide gel electrophoresis (SDS-PAGE) and subsequently underwent $\operatorname{IgE}$ immunoblotting to detect IgE-binding proteins.

The results of the skin tests were negative for all the aeroallergens except for $A$ altissima pollen (wheal, $12 \times 9 \mathrm{~mm}$; histamine control, $7 \times 6 \mathrm{~mm}$ ). SDS-PAGE revealed multiple bands (between 10 and $80 \mathrm{kDa}$ ), whereas immunoblotting revealed 3 IgE-binding bands (14, 25, and $70 \mathrm{kDa}$ ) (Figure). The result of the skin prick test with $A$ altissima extract was negative in the 2 controls.

Concentrations of airborne $A$ altissima pollen in the general atmosphere may be low, unlike local concentrations in the area where the tree is located. In addition, the pollen period coincides with that of many other autochthonous and allergenic plants. Consequently, A altissima pollen is often not included

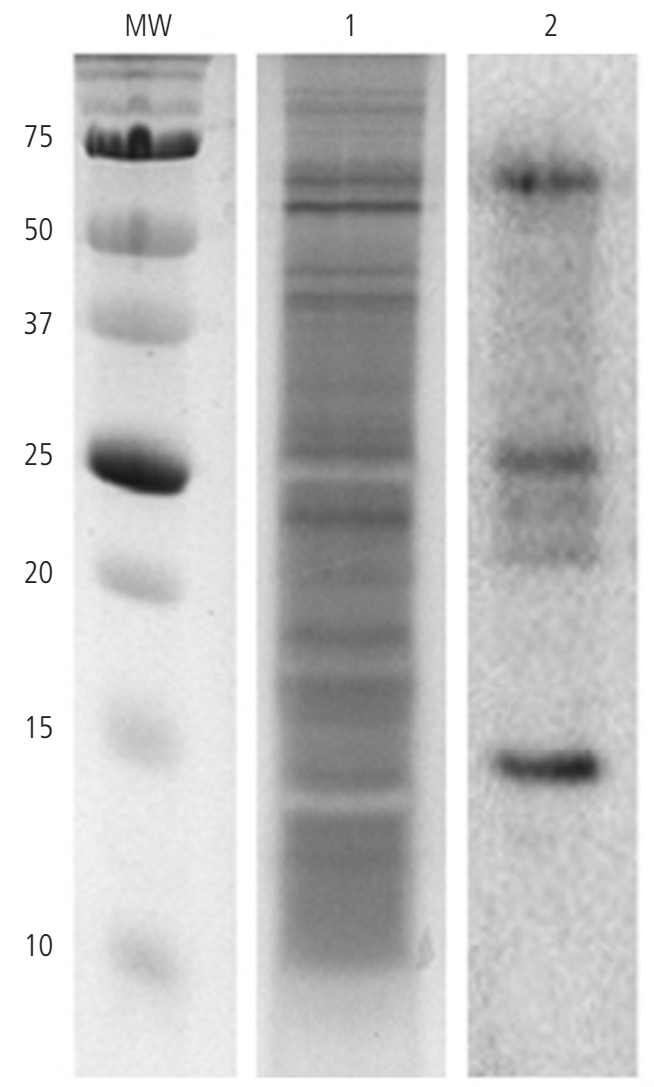

Figure. Sample extract of Ailanthus altissima pollen. Lane 1, electrophoretic profile (SDS-PAGE); Lane 2, IgE immunoblotting. MW indicates molecular weight markers ( $\mathrm{kDa}$ ). in the calendar of allergenic pollen concentrations or in routine diagnostic allergy tests.

Respiratory symptoms suggestive of allergy to A altissima pollen have been reported in a small number of patients $[3,4]$, and, in some cases, an immunoallergological study was performed [5].

A positive skin test result with $A$ altissima has generally been found in polysensitized patients, probably due to crossreactivity with other pollens [4], since $A$ altissima pollen contains cross-reactive calcium-binding proteins [6] and cross-reactive carbohydrate determinants (CCDs) [7], which have also been identified in the pollen of unrelated species.

It must be highlighted that in the present case, the patient was only sensitized to Ailanthus pollen; therefore, we can rule out the possibility that this sensitization was due to cross-reactivity with the other species tested. In addition, no IgE-binding bands corresponding to CCDs or calcium-binding proteins were detected in immunoblotting performed with the patient's serum.

Mousavi et al [5] performed SDS-PAGE with pollen extract and obtained several protein bands ranging from 10 to $110 \mathrm{kDa}$, while immunoblotting carried out with the patient's serum detected $2 \mathrm{IgE}$ binding bands with a molecular weight of 42 and $52 \mathrm{kDa}$.

The same authors subsequently studied 6 sera that were positive to $A$ altissima pollen and reported 4 different sensitization patterns based on the results of IgEimmunoblotting, as follows: one representing a patient with a wide range of proteins (25-100 $\mathrm{kDa}$, possibly associated with CCDs), another pattern recognizing proteins of between 42 and $52 \mathrm{kDa}$, a third one with $36 \mathrm{kDa}$ IgE-reactive band, and a fourth pattern with a $115-\mathrm{kDa}$ band. The 5 allergenic proteins identified by the authors were enolase, calreticulin, probable pectate lyase 6 , conserved hypothetical protein, and ras-related protein RHN1-like [8].

These results differ from those obtained with the serum in the present case, since the bands observed in immunoblotting $(14,25$, and $70 \mathrm{kDa})$ do not correspond to the molecular weight of the proteins described. However, our results are more comparable with those obtained by Dhyani et al [9], who compared the cross-reactivity of IgE-binding protein in the pollen of Prosopis juliflora with that of Ailanthus excelsa and showed that both present shared allergens that correspond to bands of $14,41,52$, and $66 \mathrm{kDa}$, while bands of 26 and $29 \mathrm{kDa}$ are specific for $P$ juliflora.

It should be noted that most studies were performed in Middle Eastern countries, where the environmental and climatic conditions differ from those in our area; therefore, we might speculate that the allergenic characteristics of the pollen could be different. In this regard, variations in the allergenic protein composition of the $A$ altissima pollen collected over 2 consecutive years have been observed [10].

Based on the results obtained, and to our knowledge, this is the first report of a patient monosensitized to A altissima pollen, with a sensitization pattern that differs from those described above. Unfortunately, we were unable to identify proteins at the molecular level despite trying to compare them with proteins described in molecular databases. The allergologic diagnosis should take local flora into account. 


\section{Funding}

The authors declare that no funding was received for the present study.

\section{Conflicts of Interest}

The authors declare that they have no conflicts of interest.

\section{References}

1. Sanz Elorza M, Dana Sánchez ED \& Sobrino Vesperinas E, eds. 2004. Atlas de las Plantas Alóctonas Invasoras en España. Dirección General para la Biodiversidad. Madrid, 384 pp.

2. Navarro C, Muñoz Garmendia F. 2015. Ailanthus Desf. [nom. Cons.], in Muñoz F, Navarro C, Quintanar A, Buira A (eds.). Flora iberica 9: 110-113. Real Jardín Botánico, CSIC, Madrid.

3. Ballero M, Ariu A, Falagiani P. Allergy to Ailanthus altissima (tree of heaven) pollen. Allergy. 2003;58:532-3.

4. Maxia A, Maxia L. Ailanthus altissima (Miller) Swingle as a cause of immunoallergic respiratory manifestations. Rendiconti Seminario Facoltà Scienze Università Cagliari 2003; Vol 73 Fasc 1.

5. Mousavi F, Majd A, Shahali Y, Ghahremaninejad F, Kardar G, Pourpak Z. Pollinosis to tree of heaven (Ailanthus altissima) and detection of allergenic proteins: a case report. Ann Allergy Asthma Immunol. 2016;116:374-5.

6. Tinghino $R$, Twardosz A, Barletta B, Puggioni EM, lacovacci P, Butteroni $C$, et al. Molecular, structural, and immunologic relationships between different families of recombinant calcium-binding pollen allergens. J Allergy Clin Immunol. 2002;109:314-20.

7. lacovacci $P$, Pini $C$, Affeni $C$, Barletta $B$, Tinghino $R$, Schininà $E$, et al. A monoclonal antibody specific for a carbohydrate epitope recognizes an IgE-binding determinant shared by taxonomically unrelated allergenic pollens. Clin Exp Allergy. 2001;31:458-65.

8. Mousavi F, Majd A, Shahali Y, Ghahremaninejad F, Shokouhi Shoormasti R, Pourpak Z. Immunoproteomics of tree of heaven (Ailanthus altissima) pollen allergens. J Proteomics. 2017;154:94-101.

9. Dhyani A, Arora N, Gaur SN, Jain VK, Sridhara S, Singh BP. Analysis of $\mathrm{lg} \mathrm{E}$ binding proteins of mesquite (Prosopis juliflora) pollen and cross-reactivity with predominant tree pollens. Immunobiology. 2006;211:733-40.

10. Mousavi F, Shahali Y, Pourpak Z, Majd A, Ghahremaninejad F. Year-to-year variation of the elemental and allergenic contents of Ailanthus altissima pollen grains: an allergologic study. Environ Monit Assess. 2019;191:362.

Manuscript received February 10, 2020; accepted for publication April 30, 2020.

Jaume Martí-Garrido

Allergology Service

Hospital Universitari de Bellvitge

c/ de la Feixa Llarga, s/n

08907 L'Hospitalet de Llobregat, Barcelona, Spain

E-mail: jmartig@bellvitgehospital.cat 